\title{
Color Removal of Some Textile Dyes from Aqueous Solutions Using Trametes versicolor
}

\author{
Bazı Tekstil Boyar Maddelerinin Trametes versicolor ile Sulu \\ Çözeltilerden Renginin Giderimi
}

\author{
Research Article \\ Özgecan Erdem* and Nilüfer Cihangir \\ Hacettepe University Department of Biology, Faculty of Science, Beytepe, Ankara, Turkey.
}

\section{A B S TR ACT}

\begin{abstract}
yes are used in textile industry frequently. Wastewater treatment with biological methods is effective and also economic. Trametes versicolor was used to degrade Reactive Blue 19, Acid Black 194, Reactive Orange 12, Reactive Red 120 and Reactive Blue $21 \mathrm{in}$. As a result of the comparison of decolorization percentage, Reactive Blue 19 (Solazol Blue BB) had the maximum rate as $99 \%$. Optimum pH for decolorization of Reactive Blue 19 was determined as 4, decolorization was not affected from low temperature, and however decreased decolorization rate was observed when the temperature increased over $60^{\circ} \mathrm{C}$. Increasing dye concentration effected negatively decolorization process. According to these results, T. versicolor deserves notable attention for decolorization of dyes in wastewater treatment.
\end{abstract}

\section{Key Words}

Biodegradation, decolorization, Reactive Blue 19, Trametes versicolor.

\section{öz}

oyar maddeler, tekstil endüstrisinde sıklıkla kullanılmaktadırlar. Biyolojik yollarla atık suların arıtımı, etkili bir yöntem olmasının yanı sıra aynı zamanda ekonomiktir. Bu çalışmada, Reactive Blue 19 (Reaktif Mavi 19), Acid Black 194(Asit Siyah 194), Reactive Orange 12 (Reaktif Turuncu 12), Reactive Red 120 (Reaktif Kırmızı 120) ve Reactive Blue 21(Reaktif Mavi 21) boyar maddelerini biyolojik olarak parçalamak amacıyla Trametes versicoIor kullanılmıştır. Renk giderme yüzdelerinin karşılaştırılması sonucunda, Reactive Blue 19 boyasında \%99 ile en yüksek oranda giderim elde edilmiştir. Biyolojik olarak Reactive Blue 19 boyar maddesinin giderimi için en uygun pH 4 olarak belirlenirken, boya gideriminin düşük sıcaklıklardan etkilenmediği ancak $60^{\circ} \mathrm{C}$ 'nin üzerine çıkıldığında renk giderme oranının azaldığı belirtilmiştir. Artan boya derişimi renk giderimi sürecini ters yönde etkilemiştir. Elde edilen sonuçlara göre, atık su artımında boyar maddelerin giderimi için T. versicolor'un dikkat çekici bir alternatif olabileceği düşünülmektedir.

\section{Anahtar Kelimeler}

Biyodegradasyon, Renk Giderimi, Reactive Blue 19, Trametes versicolor.

Article History: Received: May 22, 2017; Revised: Aug 2, 2017; Accepted: Sep 29, 2017; Available Online: Dec 25, 2017. DOI: $10.15671 / \mathrm{HJBC} .2018 .190$

Correspondence to: Ö. Erdem, Hacettepe University Department of Biology, Faculty of Science, Beytepe, Ankara, Turkey. 


\section{INTRODUCTION}

It is well known that dyes have been used in the textile industry. During the manufacturing process, these chemical agents discharge to the environment such as lake, river etc., Removal of the color from waste water has been studied because of its toxic effect to living organisms as well as to the environmental pollution $[1,2]$. Presence of dyes in the discharged wastewater prevents the light penetration, thus reduces the photosynthetic activity and dissolved oxygen concentration. Consisting anaerobic environment is a disadvantage for aquatic aerobic organisms $[3,4] \mathrm{pH} 5-0$, glucose at $3-5 \%(\mathrm{w} / \mathrm{v})$.

Several microorganisms are used for decolorization studies. One of the most widely used microorganisms are white rot fungi. Trametes versicolor is a white rot fungus which provides the degradation of wood by enzymatic reactions and consequently, recycle the minerals and nutrients for itself and the other organisms in ecosystem. Enzymes which they have; laccase, lignin peroxidase, manganese peroxidase, tyrosinase are used for industrial applications such as bleaching, textile waste water treatment, modifications of biopolymers and bioremediation $[3,5]$.

Reactive dyes are azo-based chromophores, which form compounds with different types of reactive groups. These dyes are binding to textile fibrils such as cotton with covalent bond differently from other synthetic dyes. Reactive dyes are widely used in textile industry due to their bright colors, rapid dissolution in water and simple applicability. Soluble reactive dyes constitute problems because of discharging without treatment. Therefore, dye containing wastewaters treatment before discharging to environment is important [2].

In this study, we investigated decolorization ability of Trametes versicolor ATCC 200801 of five different synthetic textile dye Reactive Blue 19, Acid Black 194, Reactive Orange 12, Reactive Red 120 and Reactive Blue 21. The highest decolorization rate of 99\% was reported with Reactive Blue 19 studies.

\section{MATERIALS and METHODS \\ Dyes}

Solazol Blue BB (C.I. Reactive Blue 19), Neutrilan Black (C.I. Acid Black 194), Reactive Bright Yellow (C.I. Reactive Orange 12), Reactive Red C-XDR (C.I. Reactive Red 120) and Solazol Turquoise Blue (C.I. Reactive Blue 21) (Figure 1) were obtained from Piko Kimya Textile Industry and Trade Co. Ltd. (Istanbul, Turkey). Stock solutions of dyes were prepared by dissolving the powdered dyestuff in distilled water for adjusting determined concentrations. Dye solutions were autoclaved at $121^{\circ} \mathrm{C}, 15$ for 15 minutes before adding to the growth medium.

\section{Microorganism}

The white rot fungus Trametes versicolor ATCC 200801 was obtained from Hacettepe University, Department of Biology. Trametes versicolor ATCC 200801 was maintained by serial transfers and kept on Potato Dextrose Agar (PDA) slants at $4^{\circ} \mathrm{C}$.

\section{Pre-Incubation of Trametes versicolor}

T. versicolor ATCC 200801 was incubated for 7 days at $30^{\circ} \mathrm{C}$ in PDA slant. After incubation mycelium suspension of $T$. versicolor was prepared with the sterile saline solution $(0.9 \% \mathrm{NaCl}) .5 \mathrm{ml}$
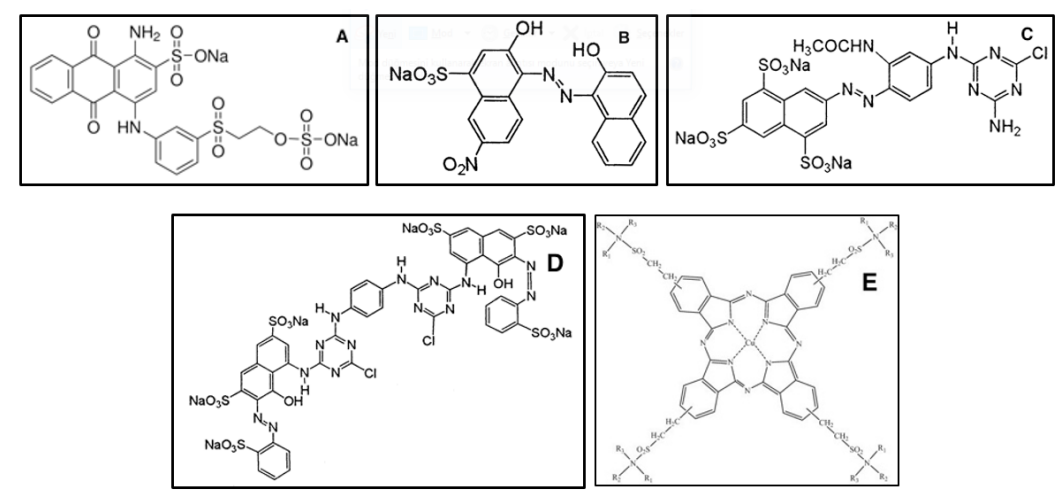

Figure 1. Chemical structure of dyes (A) Reactive Blue 19, (B) Acid Black 194, (C) Reactive Orange 12, (D) Reactive Red 120, (E) Reactive Blue 21. 
of mycelium suspension was inoculated into 250 $\mathrm{ml}$ Erlenmayer flasks containing Vogel medium. Vogel medium which was used for T. versicolor ATCC 200801 growth and decolorization studies required $20 \mathrm{~g}$ glucose, $2 \mathrm{~g} \mathrm{NH}_{4} \mathrm{NO}_{3}$ and $10 \mathrm{ml}$ solution of trace elements per liter [6]. The $\mathrm{pH}$ of the medium was adjusted to 4.7 with $1 \mathrm{M} \mathrm{HCl}$ and 1 $\mathrm{M} \mathrm{NaOH}$. Culture of Trametes versicolor was preincubated for 6 days at $30^{\circ} \mathrm{C}, 150 \mathrm{rpm}$.

\section{Decolorization Assays}

The effects of inoculum concentration $(1-5 \mathrm{ml})$, initial pH (2-9), carbon sources (glucose, fructose, maltose, pectin, xylose, starch), nitrogen sources $\left(\mathrm{NH}_{4} \mathrm{NO}_{3}\right.$, peptone, yeast extract, $\left(\mathrm{NH}_{4}\right)_{2} \mathrm{SO}_{4} \mathrm{KNO}_{3}$ $\left.\mathrm{NH}_{4} \mathrm{Cl}, \mathrm{NaNO}_{3}\right)$, temperature $\left(10-80^{\circ} \mathrm{C}\right)$, agitation rate (0-200 rpm), dye concentration (50-500 $\left.\mathrm{mg} . \mathrm{L}^{-1}\right)$ were investigated.

In order to examine duration of dye decolorization, after pre-incubation, $3 \mathrm{ml}$ of inoculum and $1 \mathrm{ml}$ of $50 \mathrm{mg} . \mathrm{L}^{-1}$ dye solution were added to the medium and incubated at $30^{\circ} \mathrm{C}, 150 \mathrm{rpm}$. During the incubation period, $3 \mathrm{ml}$ of samples were taken half-hourly from flask and the concentration of the dye in the supernatant was determined by reading the absorbance at maximum wave length of determined dye. After pre-incubation $1 \mathrm{ml}$ of $50 \mathrm{mg} \cdot \mathrm{L}^{-1}$ dye solutions were added to the Vogel medium and incubated in order to select most biodegraded dye.

Dead biomass was prepared with the purpose of comparison decolorization activity between heat-killed and living biomass. In order to obtain dead biomass, $6^{\text {th }}$ day-old culture was filtered and washed several times with distilled water. Obtained culture was autoclaved at $110^{\circ} \mathrm{C}, 25$ minutes. $3 \mathrm{ml}$ of heat-killed culture was added to the $50 \mathrm{mg} \cdot \mathrm{L}^{-1}$ dye solution and incubated at $30^{\circ} \mathrm{C}, 150 \mathrm{rpm}$.

Uninoculated flasks containing Reactive Blue 19 were used as control samples.

Unless otherwise stated, all flasks were incubated at $30^{\circ} \mathrm{C}, 150 \mathrm{rpm}$ for 2 hours for decolorization studies.

\section{Analytical Methods Dry Weight Determination}

After incubation, each culture was filtered through a filter paper using a vacuum pump. Samples were dried and dry weights were calculated.

\section{Color Determination}

Absorbance measurements were performed using a Shimadzu UV-1700 spectrophotometer. The wavelength of maximum absorbance of the dyes studied was given at Table 1.

Table 1. Maximum absorbance of dyes.

\begin{tabular}{ccc}
\hline \multicolumn{1}{c}{ Dyes } & Color Index & \\
\hline Solazol Blue BB & Reactive Blue 19 & 609 \\
\hline Neutrilan Black & Acid Black 194 & 570 \\
\hline $\begin{array}{c}\text { Reactive Bright } \\
\text { Yellow }\end{array}$ & Reactive Orange 12 & 364 \\
\hline $\begin{array}{c}\text { Reactive Red } \\
\text { C-XDR }\end{array}$ & Reactive Red 120 & 536 \\
\hline $\begin{array}{c}\text { Solazol Turquoise } \\
\text { Blue }\end{array}$ & Reactive Blue 21 & 660 \\
\hline
\end{tabular}

The percentage of decolorization was determined with reading the absorbance of supernatant at specified wavelength. The percentage was calculated with below stated equation:

Decolorization $=\left(\mathrm{Abs}_{\mathrm{i}}-\mathrm{Abs}_{\mathrm{f}}\right) \times 100 / \mathrm{Abs}_{\mathrm{i}}$

Abs: initial absorbance

Abs $_{\mathrm{f}:}$ final absorbance.

\section{RESULTS}

\section{Detection of Optimum Incubation Time of Trametes versicolor for Decolorization}

To investigate the optimum inoculation time of Trametes versicolor, after incubation, every 24 hours decolorization rate and dry weight were calculated. According to the results, $6^{\text {th }}$ day of incubation was found suitable for decolorization studies with $99 \%$ removal of dye as given at Figure 2 .

\section{Selecting Most Biodegraded Dye}

To investigate the most biodegraded dye; Solazol Blue BB, Neutrilan Black, Reactive Bright Yellow, Reactive Red C-XDR and Solazol Turquoise Blue were used in this study. Trametes versicolor could decolorize Solazol Blue BB at rate of $99 \%$ in 2 hours as seen in the Table 2. Thus, Reactive Blue 19 was selected as most biodegraded dye as seen in Figure 3 and all experiments were carried on with this dye. 


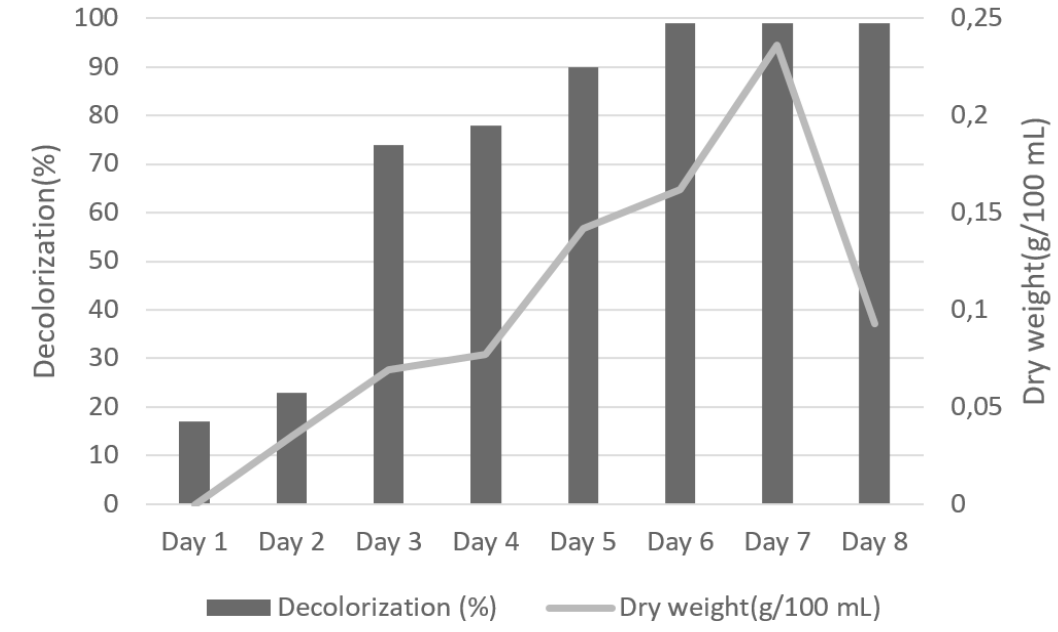

Figure 2. Reactive Blue 19 decolorization and dry weight of Trametes versicolor.

Table 2. Percentage of decolorization of dyes with Trametes versicolor.

\begin{tabular}{cc}
\hline Dyes & Decolorization (\%) \\
\hline Solazol Blue BB & 99 \\
\hline Neutrilan Black & 83 \\
\hline Reactive Bright Yellow & 76 \\
\hline Reactive Red & 56 \\
\hline Solazol Turquoise Blue & 85
\end{tabular}

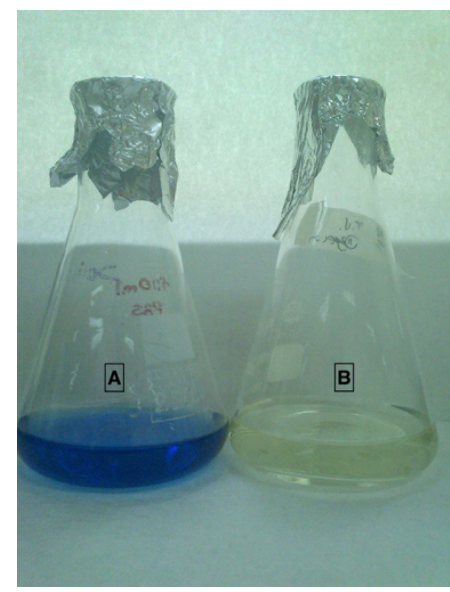

Figure 3. Decolorization of Reactive Blue 19 by Trametes versicolor after 2 hour incubation at $30^{\circ} \mathrm{C}, 150 \mathrm{rpm}(A)$ Control; 50 mg.L-1 dye solution (B) decolorized product.

Table 3. Effect of $\mathrm{pH}$ on decolorization of Reactive Blue 19.

\begin{tabular}{ccccccccc}
\hline $\mathbf{p H}$ & 2 & 3 & 4 & 5 & 6 & 7 & 8 & 9 \\
\hline Decolorization (\%) & 39 & 66 & 97 & 70 & 55 & 15 & 18 & 16 \\
\hline
\end{tabular}

\section{Selecting Most Efficient Inoculum Concentration}

The dye decolorization experiments were carried out in Vogel medium with five different inoculum concentrations; $1 \mathrm{ml}, 2 \mathrm{ml}, 3 \mathrm{ml}, 4 \mathrm{ml}$ and $5 \mathrm{ml}$. Most efficient inoculum concentration was determined as $3 \mathrm{ml}$ and the results are summarized in Figure 4. According to the results obtained from these experiments, further experiments were done with $3 \mathrm{ml}$ of inoculum concentration.

\section{Detecting of Decolorization Time of Reactive Blue 19 by Trametes versicolor}

To investigate the decolorization time, after incubation every $30^{\text {th }}$ minutes, a sample was taken from the decolorization medium and the concentration of the dye in the supernatant was determined by reading the absorbance at $609 \mathrm{~nm}$. Maximum decolorization efficiency (99\%) was occurred at the end of the $2^{\text {nd }}$ hour (Figure 5).

\section{Effect of $\mathrm{pH}$ on decolorization of Reactive Blue 19}

In order to determine determine the effect of different $\mathrm{pH}$ values, initial $\mathrm{pH}$ of decolorization medium was adjusted to 2 between 9. As indicated in the Table 3, maximum decolorization was obtained at $\mathrm{pH}$ 4. High $\mathrm{pH}$ levels affected negatively the decolorization ability of Trametes versicolor. 


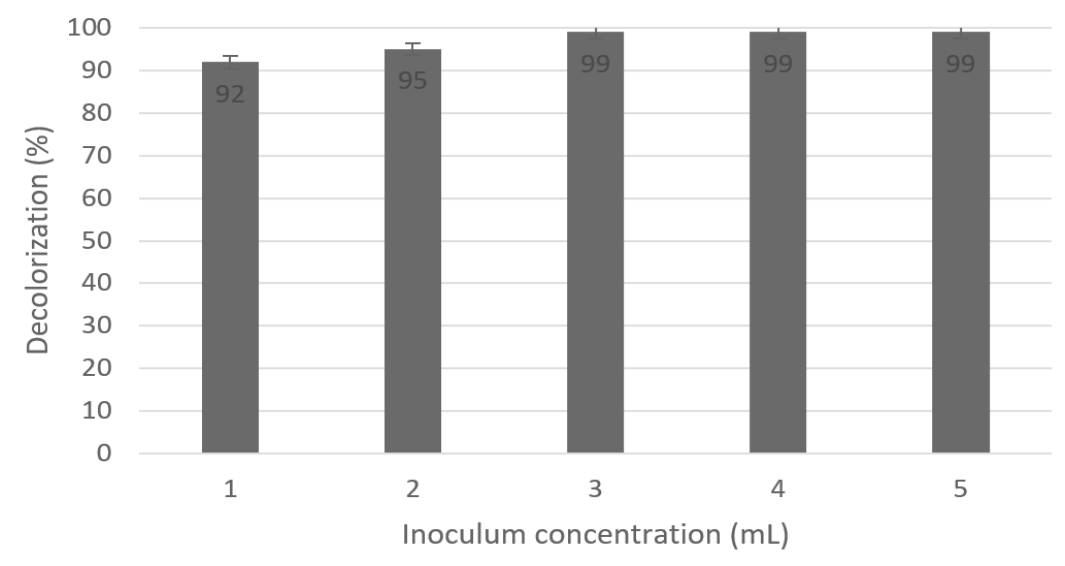

Figure 4. Effect of initial inoculum concentration on decolorization of Reactive Blue 19 by Trametes versicolor.

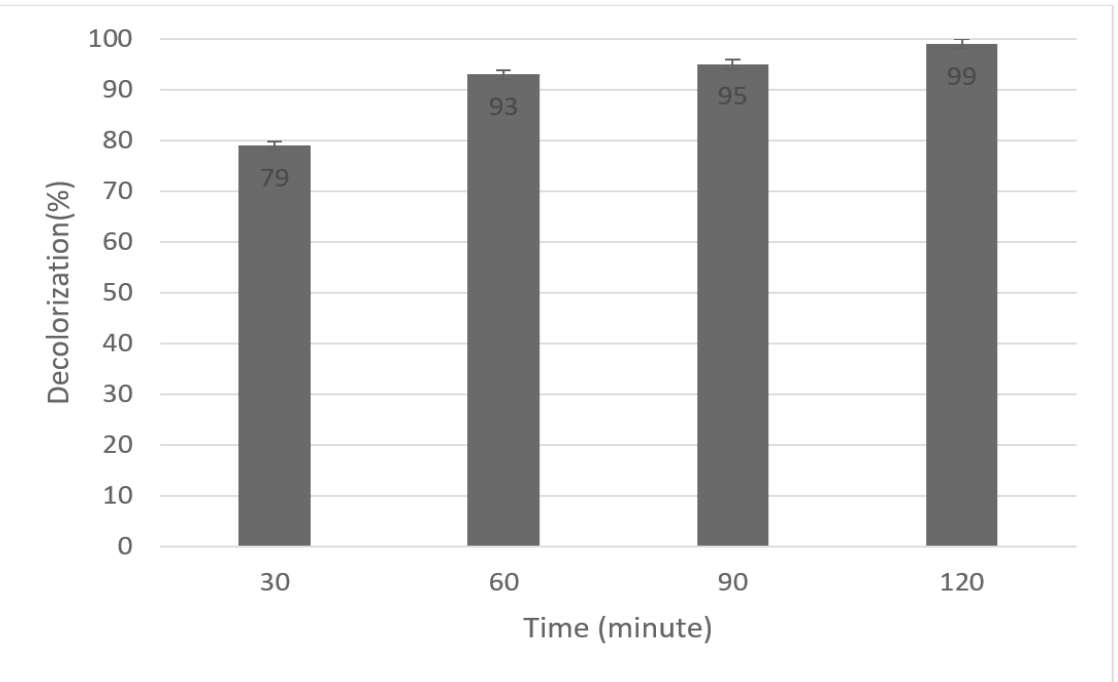

Figure 5. Time course of decolorization Reactive Blue 19 at $50 \mathrm{mg} \cdot \mathrm{L}^{-1}$.

\section{Effect of Carbon and Nitrogen Sources on Decolorization of Reactive Blue 19}

To examine the effect of carbon and nitrogen sources on the dye removal, glucose, fructose, maltose, pectin, xylose, starch were used as carbon sources, on the other hand peptone, yeast extract, $\left(\mathrm{NH}_{4}\right)_{2} \mathrm{SO}_{4}, \mathrm{KNO}_{3}, \mathrm{NH}_{4} \mathrm{Cl}, \mathrm{NaNO}_{3}, \mathrm{NH}_{4} \mathrm{NO}_{3}$ were tested as nitrogen sources. As seen in the Table 4, maximum decolorization was observed at mediums with glucose (99\%), xylose (99\%) and maltose (98\%). The most effective decolorization occurred in $\mathrm{NH}_{4} \mathrm{NO}_{3}$ (99\%) and peptone (97\%) (Table 5). Decolorization of Reactive Blue 19 was decreased perceptibly with the lack of carbon and nitrogen sources.

Effect of Temperature on Decolorization of Reactive Blue 19
Effect of temperature $\left(10-80^{\circ} \mathrm{C}\right)$ on decolorization of Reactive Blue 19 are shown in Figure 6 . The results show that low temperature did not affect the decolorization, in addition to this, with increasing of temperature, rate of decolorization

Table 4. Effect of different carbon sources on decolorization of Reactive Blue 19.

\begin{tabular}{ccc}
\hline Carbon sources & $\begin{array}{c}\text { Decolorization } \\
\mathbf{( \% )}\end{array}$ & $\begin{array}{c}\text { Dry weight } \\
(\mathbf{g} / \mathbf{1 0 0} \mathbf{~ m L})\end{array}$ \\
\hline Fructose & 56 & 0.05 \\
\hline Maltose & 98 & 0.20 \\
\hline Pectin & 45 & 0.17 \\
\hline Xylose & 99 & 0.25 \\
\hline Starch & 86 & 0.48 \\
\hline Glucose & 99 & 0.27 \\
\hline $\begin{array}{c}\text { Without any carbon } \\
\text { source }\end{array}$ & 40 & 0.02 \\
\hline
\end{tabular}


Table 5. Effect of different nitrogen sources on decolorization of Reactive Blue 19.

\begin{tabular}{ccc}
\hline Nitrogen sources & $\begin{array}{c}\text { Decolorization } \\
\mathbf{( \% )}\end{array}$ & $\begin{array}{c}\text { Dry weight } \\
(\mathbf{g} / 100 \mathbf{~ m L})\end{array}$ \\
\hline Peptone & 97 & 0.32 \\
\hline Yeast extract & 37 & 0.22 \\
\hline$\left(\mathrm{NH}_{4}\right)_{2} \mathrm{SO}_{4}$ & 87 & 0.1 \\
\hline $\mathrm{KNO}_{3}$ & 31 & 0.06 \\
\hline $\mathrm{NH}_{4} \mathrm{Cl}$ & 86 & 0.17 \\
\hline $\mathrm{NaNO}_{3}$ & 51 & 0.06 \\
\hline $\mathrm{NH}_{4} \mathrm{NO}_{3}$ & 99 & 0.29 \\
\hline $\begin{array}{c}\text { Without any nitrogen } \\
\text { source }\end{array}$ & 24 & 0.06 \\
\hline
\end{tabular}

started to decrease.

\section{Effect of Agitation Speed on Decolorization of Reactive Blue 19}

Effect of agitation speed (0-150 rpm) on decolorization of Reactive Blue 19 are shown in Figure 7 . The results show that agitation speed did not affect the decolorization. In the current study, Trametes versicolor also has a high decolorization rate $(96 \%)$ on the static conditions. High decolorization yield in static conditions is an advantage for wastewater treatment due to its energy conservation.

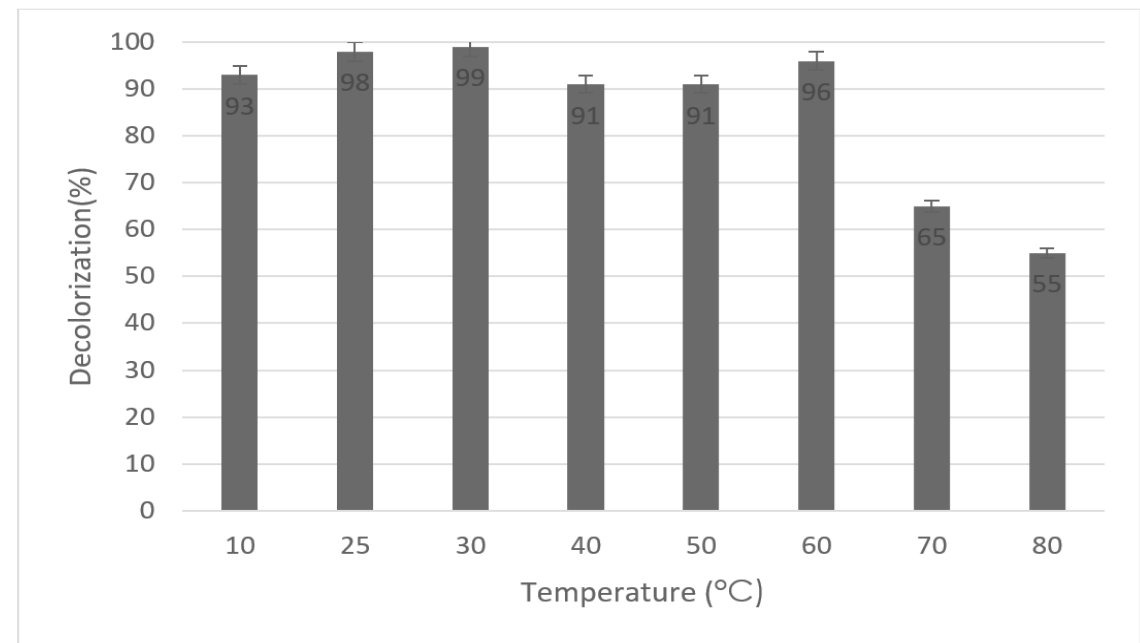

Figure 6. Effect of temperature on decolorization of Reactive Blue 19.

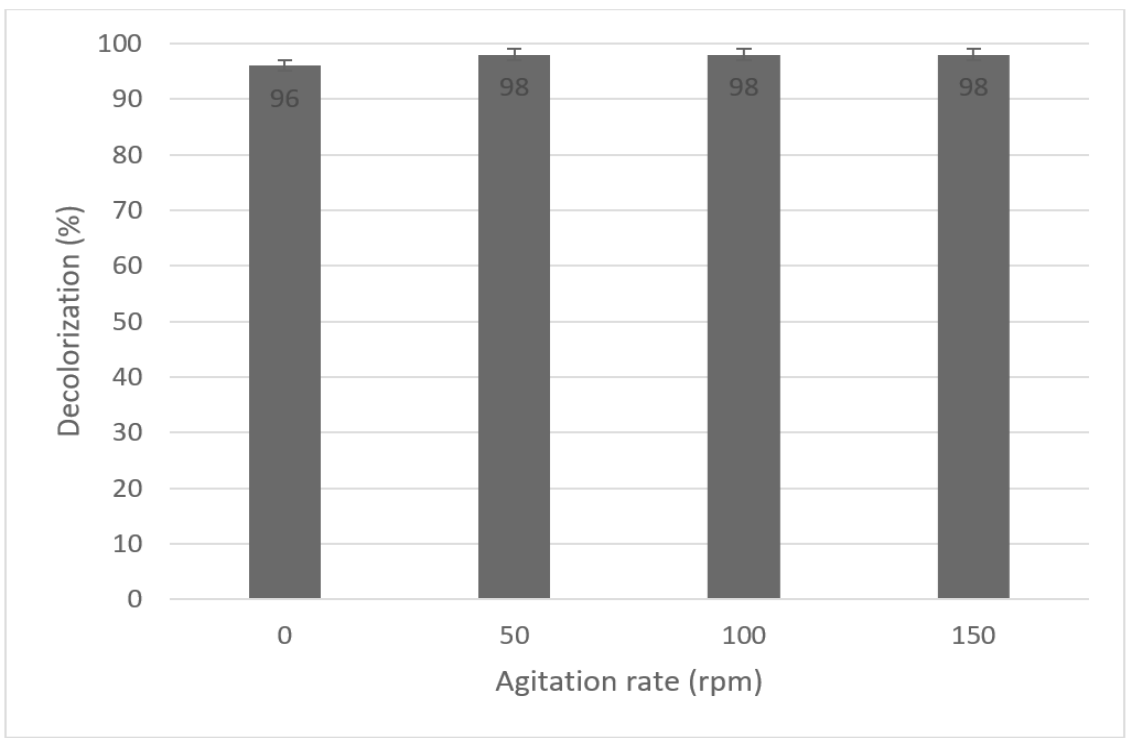

Figure 7. Effect of agitation rate on decolorization of Reactive Blue 19. 


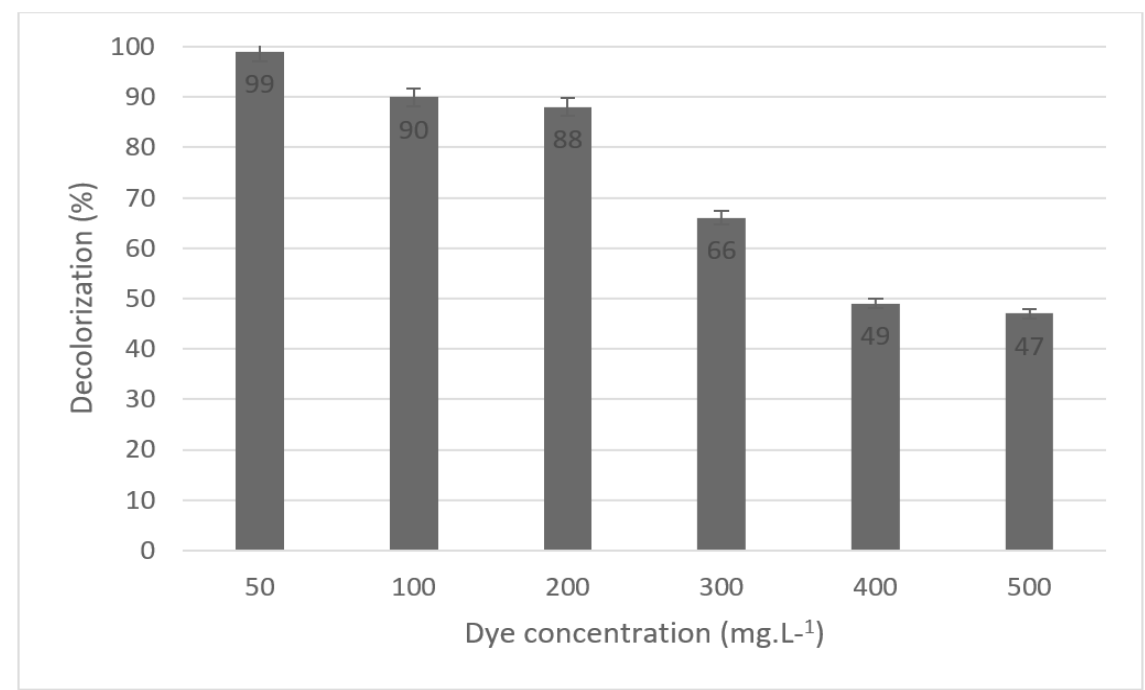

Figure 8. Effect of initial dye concentration on decolorization of Reactive Blue 19.

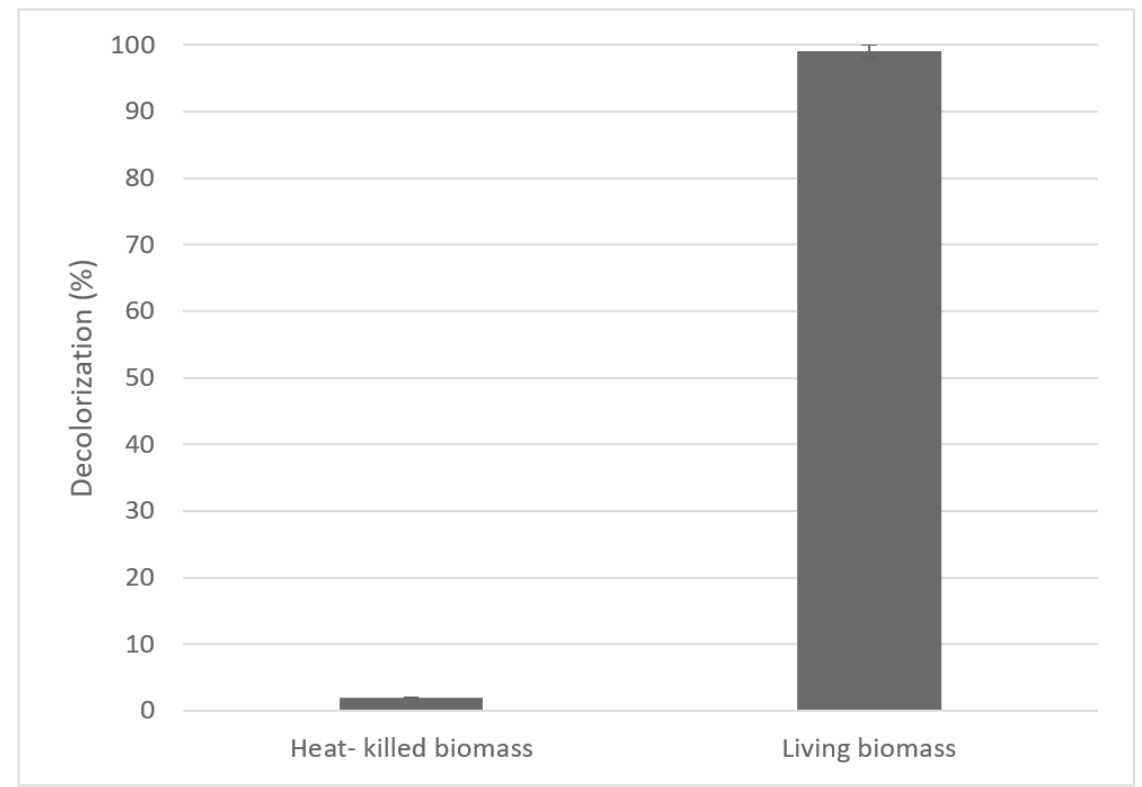

Figure 9. Reactive Blue 19 decolorization activities of living biomass and heat-killed biomass.

\section{Effect of Increasing Dye Concentration on Decolorization of Reactive Blue 19}

After the study which continued with 50 mg. $\mathrm{L}^{-1} \mathrm{dye}$ concentration, 100, 200, 300, 400 and $500{\mathrm{mg} . \mathrm{L}^{-1}}^{-1}$ dye concentrations were also tested. As given at Figure 8, with the increasing of dye concentration, the decolorization ability of $T$. versicolor was decreased.

\section{Decolorization of Reactive Blue 19 with Heat- Killed Biomass}

Comparison of decolorization activity between dead and living biomass was shown at Figure 9. Heat killed biomass has a very low decolorization activity. Beside this, living biomass have a remarkable bioremoval ability. These results showed that, Trametes versicolor could decolorize Reactive Blue 19 through biodegradation rather than biosorption.

\section{DISCUSSION}

The pollution of water, soil and air with toxic and carcinogenic chemicals is one of the major environmental problems. This pollution can cause accumulation of toxic materials in food 
chains. White-rot fungi are one of the important microorganism which are attracted attention in bioremoval of pollutants due to their ligninolytic enzymes, including laccase, manganese peroxidase $(\mathrm{MnP})$ and lignin peroxidase (LiP) [7]. Trametes versicolor is one of the white rot fungi which have ability of toxic chemical substance degradation.

When effects of some parameters were analyzed in literature, results which are closer and lower than ours are draw attention. Radha et. al [8] described optimum inoculum concentration of Phanerochaete chrysosporium a white rot fungi as $2 \mathrm{ml}$. Some previous studies also indicated that $10 \%$ of inoculum concentration is sufficient for treatment of wastewater [9]. As indicated in the Figure 3, our studies showed that low concentration of inoculum is also efficient and has a high decolorization rate (92\%).A study performed by Nyanhongo et.al [10] showed similar results like Trametes modesta had maximum decolorization of Reactive Blue 19 (98\%) and Reactive Blue 221 (100\%) at pH 4.5. Similar observations were described by Chagas et.al. [11] showed that Phanerochaete chrysosporium could decolorize Amaranth at pH 4.5 (98.5\%). Some previous studies also indicated that, Trametes versicolor has similar laccase activity with glucose and maltose as a carbon sources [12]. Glucose is a commonly used and suitable carbon sources for fungi. However, it is an expensive source for the industrial area. Hence, researchers are looking for another carbon sources [13]. Kapdan et al. [14] used starch, fructose and molasses instead of glucose considering this situation. Maximum decolorization of Everzol Turquoise Blue $G$ was reached with glucose as a carbon source. A study reported by Zhang et.al. [15] was stated that glucose, maltose and cellobiose were the most suitable sources while sucrose, lac tose and xylan were not. In our study glucose also found to be the most suitable carbon source closer to the other researches. Nitrogen sources effect every microorganism differently. Some white rot fungi grow and produce enzymes better with limited supply of nitrogen while some of them show better decolorization in nitrogen adequate medium. The decolorization yield is depending on the complexity of dye structure and availability of nitrogen in the medium [16]. When a comparison was made with other researches, a previous study also showed that
$\mathrm{NH}_{4} \mathrm{NO}_{3}$ was the most effective nitrogen sources as our study for decolorization of Aspergillus sojae [17]. Higher temperatures are resulted with high initial rates of enzymatic reaction[18]. In this study high decolorization yield was obtained with a wide temperature $\left(10-60^{\circ} \mathrm{C}\right)$. In a previous study on the performance of Trametes versicolor, Romera et al. [19] indicated that $T$.versicolor has a decolorization rate over $80 \%$ at $25^{\circ} \mathrm{C}$. Dhakar et.al. [20] also showed that Trametes hirsuta can tolerate wide temperature range $\left(4-48^{\circ} \mathrm{C}\right)$ for production of laccase. Temperature is one of the important parameters, which may influence enzyme activity. Trametes versicolor has enzymes which show ligninolytic activity like laccase, lignin peroxidase and manganese peroxidase. According to the results, decolorization of Reactive Blue 19 was occurred through biodegradation in our study. Optimum pH and temperature are the important parameters which the enzyme was stable and retained its activity [18].

According to the study that performed by Champagne and Ramsey, 250 rpm was the optimum agitation speed for decolorization of Amaranth dye with Trametes versicolor [21]. Previous study also indicated that $T$. versicolor has $88 \%$ decolorization rate at $100 \mathrm{rpm}$ with 4 days incubation [22] Schizosaccharomyces pombe, Kluyveromyces marxianus, Candida sp., C. tropicalis, C. lipolytica, C. utilis, C. quilliermendii and C. membranaefaciens. In another study on Funalia trogii by Yesilada et al. $[23,24]$ showed that the highest decolorization rate for Astrazon Red FBL dye was obtained at 100-150 rpm. In our study, results are showed that decolorization process do not affect from agitation speed.

The white rot fungi Trametes versicolor ATCC 200801 could decolorize Reactive Blue 19 dye up to $99 \%$ within 2 hours in optimized conditions. Decolorization activity decreased with increasing of $\mathrm{pH}$. Optimum $\mathrm{pH}$ was determined as 4. Decolorization ability of $T$. versicolor was changed with different carbon and nitrogen sources. Reactive Blue 19 removal yield was found $99 \%$ at xylose and glucose bearing medium and followed by maltose bearing medium (98\%). The highest decolorization (99\%) rate was observed with $\mathrm{NH}_{4} \mathrm{NO}_{3}$ as a nitrogen source. Decolorization was decreased at higher than $60^{\circ} \mathrm{C}$. Agitation speed did not affect 
the removal of Reactive Blue 19. Decolorization yields decreased with an increase in dye concentration. Heat-killed biomass could decolorize the dye at very low percentage. This result showed that decolorization of Reactive Blue 19 dye occurred through biodegradation mechanism. Further studies should be performed which ligninolytic enzyme involved in decolorization processes. Consequently, our results showed that Trametes versicolor is an efficient microorganism for textile dye containing wastewater treatment.

\section{References}

1. G. Boduroğlu, N.K. Kılıç, G. Dönmez, Bioremoval of Reactive Blue 220 by Gonium sp. biomass, Environ. Technol., 35 (2014) 2410-2415.

2. T. Robinson, G. McMullan, R. Marchant, P. Nigam, Remediation of dyes in textile effluent: a critical review on current treatment technologies with a proposed alternative, Bioresour. Technol., 77 (2001) 247-55.

3. I.M. Banat, P. Nigam, D. Singh, R. Marchant, Microbial decolorization of textile dye containing effluents: a review, Bioresour. Technol., 58 (1997) 217-227.

4. V. Kumar, L. Wati, P. Nigam, I.M. Banat, B.S. Yadav, D. Singh, R. Marchant, Decolorization and biodegradation of anaerobically digested sugarcane molasses spent wash effluent from biomethanation plants by whiterot fungi, Process Biochem., 33 (1998) 83-88.

5. A. Leonowicz, N. Cho, J. Luterek, A. Wilkolazka, M. Wojtas-Wasilewska, A. Matuszewska, M. Hofrichter, D. Wesenberg, J. Rogalski, Fungal laccase: Properties and activity on lignin, J. Basic Microbiol., 41 (2001) 185-227.

6. N. Aktaş, A. Tanyolaç, Reaction conditions for laccase catalyzed polymerization of catechol, Bioresour. Technol., 87 (2003) 209-214.

7. M. Ellouze, S. Sayadi, White-Rot Fungi and their Enzymes as a Biotechnological Tool for Xenobiotic Bioremediation," Management of Hazardous Wastes, Intech, (2016) 104-120.

8. K.V. Radha, I. Regupathi, A. Arunagiri, T. Murugesan, Decolorization studies of synthetic dyes using Phanerochaete chrysosporium and their kinetics, Process Biochem., 40 (2005) 3337-3345.

9. M. Shahvali, M.M. Assadi, K. Rostami, Effect of environmental parameters on decolorization of textile wastewater using Phanerochaete chrysosporium, Bioprocess Eng., 23 (2000) 721-726.
10. G.S. Nyanhongo, J. Gomes, G.M. Gübitz, R. Zvauya, J. Read, W. Steiner, Decolorization of textile dyes by laccases from a newly isolated strain of Trametes modesta, Water Res., 36 (2002) 1449-56.

11. E.P. Chagas, L.R. Durrant, Decolorization of azo dyes by Phanerochaete chrysosporium and Pleurotus sajorcaju, Enzyme Microb. Technol., 29 (2001) 473477.

12. N. Mikiashvili, V. Elisashvili, S. Wasser, E. Nevo, Carbon and nitrogen sources influence the ligninolytic enzyme activity of Trametes versicolor, Biotechnol. Lett., 27 (2005) 955-9.

13. Y.D. Aracagök, N. Cihangir, Decolorization of Reactive Black 5 by Yarrowia lipolytica NBRC 1658, Am. J. Microbiol. Res., 1 (2013) 16-20.

14. I. Kapdan, F. Kargia, G. McMullan, R. Marchant, Effect of environmental conditions on biological decolorization of textile dyestuff by $C$. versicolor, Enzyme Microb. Technol., 26 (2000) 381-387.

15. X. Pan, D. Zhang, Removal of malachite green from water by Firmiana simplex wood fiber, Electron. J. Biotechnol., 12(2009) 1-10.

16. M. Asgher, Biosorption of reactive dyes: A review, Water, Air Soil Pollut., 223 (2012) 2417-2435.

17. B.H. Ryu, Y.D. Weon, Decolorization of Azo Dyes by Aspergillus sojae B-10, J. Microbiol. Biotechnol., 2 (1992) 215-219.

18. S. Ben Younes, I. Cherif, A. Dhouib, S. Sayadi, Trametes trogii: A Biologic Powerful Tool for Dyes Decolorization and Detoxification, Catal. Letters, 146 (2016) 204-211.

19. S. Romero, P. Blánquez, G. Caminal, X. Font, M. Sarrà, X. Gabarrell, T. Vicent, Different approaches to improving the textile dye degradation capacity of Trametes versicolor," Biochem. Eng. J., 31 (2006) 42-47.

20. K. Dhakar, A. Pandey, Laccase Production from a Temperature and $\mathrm{pH}$ Tolerant Fungal Strain of Trametes hirsuta (MTCC 11397), Enzyme Res., 2013 (2013) 869062.

21. P.P. Champagne, J.A. Ramsay, Reactive blue 19 decolouration by laccase immobilized on silica beads, Appl. Microbiol. Biotechnol., 77 (2007) 819-23.

22. Z. Aksu, G. Dönmez, A comparative study on the biosorption characteristics of some yeasts for Remazol Blue reactive dye., Chemosphere, 50 (2003) 1075-83.

23. O. Yesilada, D. Asma, S. Cing, Decolorization of textile dyes by fungal pellets, Process Biochem., 38 (2003) 933-938.

24. R. Sombro, N. Memon, M.I. Bhanger, A. Denizli, Horse radish peroxidase immobilized into organogel-silica composite for transformation of chlorophenols to biodegradable organic acids, Hacettepe J. Bio. Chem., 44 (2016) 351-364. 